\title{
THE ROLE OF NUTRIENTS TO BOOST THE IMMUNITY IN THE COVID-19 PANDEMIC
}

The role of nutrients to boost the immunity in the COVID-19 pandemic

O. M. Krekhovska-Lepiavko, B. A. Lokay,

S. O. Yastremska, N. I. Reha, V. Ye. Horodetskyy

I. Horbachevsky Tenopil National Medical University

e-mail: lepyavkoom@tdmu. edu.ua

Summary. Regarding the current situation of the COVID-19 pandemic, in which there is no optimal cure, the functionality and efficiency of the immune response is the key factor in the defense against viral infections. Several nutrients, especially vitamins and microelements, are crucial for the immune system to function normally. Moreover, dietary supplementations of such nutrients have beneficial impacts on the immune responses to viral infections. Studies showed that after influenza vaccination, the supplementation of vitamins $A$ and $D$ boost the humoral immunity of pediatric patients. In patients with torque teno virus (TTV), dietary supplementation with high levels of zinc resulted in improved immunity. Also, high doses of selenium had positive effects on the immune response after influenza vaccination. Regarding the COVID-19, it is fundamental to demonstrate the data on increasing the immune response to viral infections. The present review paper principally subjects influenza-like viral infections. Nonetheless, other viral infections have also been taken into consideration. Therefore, practical recommendations on using nutrients for the prevention and therapy of COVID-19 are given.

The aim of the study - to provide a complementary overview of the recently available scientific literature on the strategy of using nutraceuticals in boosting the immune system under the COVID-19 pandemic.

Materials and Methods. The study uses publications of the world scientific literature on COVID-19 infection, in particular the causes and mechanisms of its development, treatment, complications and its consequences as well as the influence of different nutrients and nutrasuticals on the course of COVID-19. This review highlights the nutritional interventions to boost the immune response in the body during viral infections, especially considering the novel coronavirus pandemic

Results. Immune system does great work in fighting foreign cells to protect the body from disease. Of course, when a global pandemic strikes the whole world, humans will feel anxious until they conquer it and be healthy. When the COVID-19 epidemic appeared, all sought to find a vaccine to counter this virus. Given a vaccine if provided, immune
Роль нутрієнтів у підвищенні імунітету при пандемії COVID-19

О. М. Креховська-Лепявко, Б. А. Локай,

С. О. Ястремська, Н. І. Рега, В. Є. Городецький

Тенопільський національний медичний університет імені І. Я. Горбачевського МОЗ України

Резюме. Аналізуючи перебіг пандемії COVID-19 без наявного на даний час оптимального лікування даного захворювання, фрункціональність та ефрективність імунної відповіді вважаються одними з ключових фракторів захисту в ході боротьби з даною інфекцією. Деякі поживні речовини, особливо вітаміни та мікроелементи, мають вирішальне значення для ефрективної роботи імунної системи. Дослідження показали, що приймання вітамінів A і D після вакцинації проти грипу підвищувало рівень гуморального імунітету в дітей. Застосування дієтичних добавок із високим вмістом цинку пацієнтами з torque teno virus (вірус гепатиту TTV) сприяв посиленню імунітету. Крім того, високі дози селену мали позитивний вплив на імунну відповідь у пацієнтів після щеплення проти грипу. Щодо інфекції COVID-19, яка також має вірусну етіологію, важливо розуміти механізми посилення імунного захисту у відповідь на вірусні ураження та розробити практичні рекомендації щодо споживання різноманітних вітамінів та мінералів для профрілактики та лікування COVID-19.

Мета дослідження - провести аналіз наукової літератури щодо стратегії використання нутрієнтів для підвищення імунної системи в умовах пандемії COVID-19.

Матеріали і методи. У дослідженні використано публікації світової наукової літератури про інорекцію COVID-19, зокрема про причини та механізми ії розвитку, лікування, ускладнення та наслідки, а також про вплив різних нутрієнтів на перебіг COVID-19. Даний огляд розкриває роль харчування у підвищенні імунної відповіді організму під час вірусних інфекцій, у тому числі при COVID-19, та механізми впливу поживних речовин на посилення імунного захисту організму.

Результати. Імунна система організму відіграє визначну роль у боротьбі з інфекційними чинниками. У відповідь на появу пандемії COVID-19, усі зусилля світових науковців були направлені на винайдення вакцини для активної протидії цьому вірусу. На сьогодні доведено, що раціональне харчування також сприяє посиленню роботи імунної системи як передової лінії захисту ор-
ISSN 2706-6282(print)

ISSN 2706-6290(online)
Вісник медичних і біологічних досліджень

Bulletin of Medical and Biological Research 
systems will need to adapt to the COVID-19-infected body. Proper nutrition can help in maintaining immune systems as the frontline of defense. Researchers believe that the deficiency of a particular nutritional element is implicated in the impaired immune responses. Nutrition principles based on using some dietary substances such as trace elements, vitamins, probiotics, and nutraceuticals may be helpful in the possible prevention and management of COVID-19. Control of the COVID-19 outbreak and future epidemics requires global efforts among clinicians, immunologists, nutritionists, researchers, veterinarians, and pharmacists. Also, public health awareness should be increased about the role of nutrition in eliminating the virus by boosting the immune system. Finally, better understanding the transmission dynamics, incubation period, and replications of COVID-19, along with finding and developing specific vaccines and therapeutics, will pave the way to end this infection soon.

Conclusions. Despite the fact that the exact intracellular mechanisms of immunostimulatory action of nutrients have not been fully studied, there is much evidence of their beneficial effects on the body's immune system, as well as their proven antioxidant and antiinflammatory activity. Nutrition plays an evidential role in the prevention and treatment of respiratory infections of varying severity. Adequate nutrition is even more important for lowand middle-income countries, where deficiencies in key vitamins and minerals expose people to greater morbidity and mortality. Low- and middle-income countries need to develop a strategy to ensure that the general population has access to optimal nutrition to strengthen the immune system, as well as to ensure a balanced diet during the treatment of patients with COVID-19.

Key words: COVID-19; viral infection; nutrition; supplements; vitamins; microelements.

\section{INTRODUCTION}

The article adduces the nutritional interventions to boost the immune response in the body during viral infections, especially considering the novel coronavirus pandemic. Due to their beneficial effects on general healthcare and disease prophylaxis, nutraceuticals have been gaining more and more importance lately [1]. Nutraceutical is composed of two words: nutrient and pharmaceutical. It has a vital role in maintaining the healthy body and thus prevents the body from diseases. Several nutraceuticals have been reported to have a significant impact on enhancing the immune system and aid in the treatment and/or protection of viral infections, particularly influenza-like diseases [1, 2]. In the current COVID-19 pandemic situation and unavailability of the drugs, these safe alternatives such as nutraceuticals can provide a significant value against the combat of COVID-19.

The aim of the study - to provide a complementary overview of the recently available scientific literature on the strategy of using nutraceuticals in boosting the immune system under the COVID-19 pandemic. ганізму. Дослідники вважають, що дефріцит певного поживного елемента призводить до порушення процесів імунних реакцій. Принципи харчування, засновані на використанні різноманітних мікроелементів, вітамінів, пробіотиків та нутрієнтів, можуть бути корисними для проорілактики та лікування COVID-19. Контроль спалаху COVID-19 та майбутніх епідемій вимагає глобальних зусиль серед лікарів, імунологів, дієтологів, дослідників, фрармацевтів та медичних сестер. Крім того, високий рівень обізнаності щодо ролі харчування у боротьбі з вірусом шляхом зміцнення імунної системи, а також краще розуміння динаміки передачі, інкубаційного періоду та реплікацій COVID-19 і пошук та розробка специфрічних вакцин та терапевтичних засобів відкриють шлях до подолання даної пандемії.

Висновки. Незважаючи на те, що точні внутрішньоклітинні механізми імуностимулюючої дії нутрієнтів не вивчені повністю, існує багато доказів їх сприятливого впливу на стан імунної системи організму, а також доведена їх антиоксидантна та протизапальна активність. Харчування відіграє доказову роль у профрілактиці та лікуванні респіраторних інорекцій різних ступенів тяжкості. Адекватне харчування є ще більш важливим для жителів країн із низьким і середнім рівнем доходів, де дефріцит ключових вітамінів і мінералів наражає людей на більшу захворюваність та смертність. Країни з низьким та середнім рівнем доходу повинні розробити стратегію для забезпечення доступу населення в цілому до оптимального харчування для зміцнення імунної системи, а також забезпечити раціональне харчування в ході лікування хворих на COVID-19.

Ключові слова: COVID-19; вірусна інфекція; харчування; поживні речовини; вітаміни; мікроелементи.

\section{MATERIALS AND METHODS}

The study uses publications of the world scientific literature on COVID-19 infection, in particular the causes and mechanisms of its development, treatment, complications and its consequences as well as the influence of different nutrients and nutrasuticals on the course of COVID-19. This review highlights the nutritional interventions to boost the immune response in the body during viral infections, especially considering the novel coronavirus pandemic. Due to their beneficial effects on general healthcare and disease prophylaxis, nutraceuticals have been gaining more and more importance lately.

\section{RESULTS AND DISCUSSION}

Numerous vitamins are crucial for the normal functions of the immune response [3]. For maintaining the vitamin homeostasis in the body, it is vital to have a varied and balanced diet [4]. The dietary supplementation of vitamin D may have positive effects on individuals who are either insufficient or deficient. Evidence supporting the role of vitamin $\mathrm{D}$ in reducing the risk of COVID-19 includes the fact that the outbreak 
occurred in winter, a time when 25-hydroxyvitamin D $(25(\mathrm{OH}) \mathrm{D})$ concentrations are lowest; that the number of cases in the Southern Hemisphere near the end of summer are low; that vitamin D deficiency has been found to contribute to acute respiratory distress syndrome; and that case-fatality rates increase with age and with chronic disease comorbidity, both of which are associated with lower vitamin D concentration [5].

Figure 1 demonstrates the mechanisms of vitamin $D$ immunomodulation. The Vit D modulation effects on the adaptive immune system were identified to occur via its direct enhancing effects on; activation of $\mathrm{T}$ cells, stimulation of antigen-presenting cells especially dendritic cells.

Systemic or locally produced 1,25(OH)2VD3 exerts its effects on several immune-cell types, including macrophages, dendritic cells (DCs), T and B cells. Macrophages and DCs constitutively express vitamin D receptor (VDR), whereas VDR expression in T cells is only upregulated following activation. In macrophages and monocytes, 1,25(OH)2VD3 positively influences its own effects by increasing the expression of VDR and the cytochrome P450 protein CYP27B1. Certain Tolllike-receptor (TLR)-mediated signals can also increase the expression of VDR. 1,25(OH)2VD3 also induces monocyte proliferation and the expression of interleukin-1 (IL-1) and cathelicidin (an antimicrobial peptide) by macrophages, thereby contributing to innate immune responses to some bacteria. 1,25(OH)2VD3 decreases DC maturation, inhibiting upregulation of the expression of MHC class II, CD40, CD80 and CD86. In addition, it decreases IL-12 production by DCs while inducing the production of IL-10. In T cells, 1,25(OH)2VD3 decreases the production of IL-2, IL-17 and interferon-y (IFNy) and attenuates the cytotoxic activity and proliferation of $\mathrm{CD}^{+}$and $\mathrm{CD}^{+} \mathrm{T}$ cells. 1,25(OH)2VD3 might also promote the development of forkhead box protein 3 (FOXP3) $)^{+}$regulatory $T\left(T_{\text {Reg }}\right)$ cells and IL-10-producing $\mathrm{T}$ regulatory type 1 (TR1) cells. Finally, 1,25(OH)2VD3 blocks B-cell proliferation, plasma-cell differentiation and immunoglobulin production. ASCs, antibody-secreting cells.

Crohn's disease, eczema, psoriasis, juvenile diabetes mellitus, asthma, multiple sclerosis, and rheumatoid arthritis, which are some important autoimmune diseases, had been identified to be closely associated with Vit D and its deficiency, also adding to its benefaction in treatment of tuberculosis, common infections of chest, urinary tract, eye and wounds, it hasbeen strongly approved in treatment of influenza, and also identified to be highly supportive in treatment of different infections including: viral, bacterial and fungal infections [6]. Also, gastrointestinal tract autoimmunity disorders consequent to valuable increase in IL-17 and IFN-y secreting T-cells numbers and a concomitant reduction in regulatory T-cells have been highly approved to occur due to absence of Vit D and its receptors [7].

Risk of lungs infections including pneumonia can be reduced after administration of Vit $D$, and it may occur through several mechanisms including, which may result in reduced amount of: replication rates of viruses and concentration of inflammatory cytokines, in contrast by considerable increased values of antiinflammatory cytokines concentrations [8]. In a recent published study, in order to reduce the risk of infection, it has been strongly recommended that people who are at the risk of influenza and/or COVID-19 infection must receive specified amount of Vit $D$ and continue to its reception according to the defined protocol for prevention, and higher dosages of Vit D3 might be useful in order to treat COVID-19 infected patients [8]. In a recent published study, association between mortality rate of COVID-19 infection and geographical latitude has been studied and possible relationship between Vit D deficiency and severity of COVID-19 infection has been strongly approved. This relationship has been reported more stronger when comparison between Scandinavian countries (with considerable

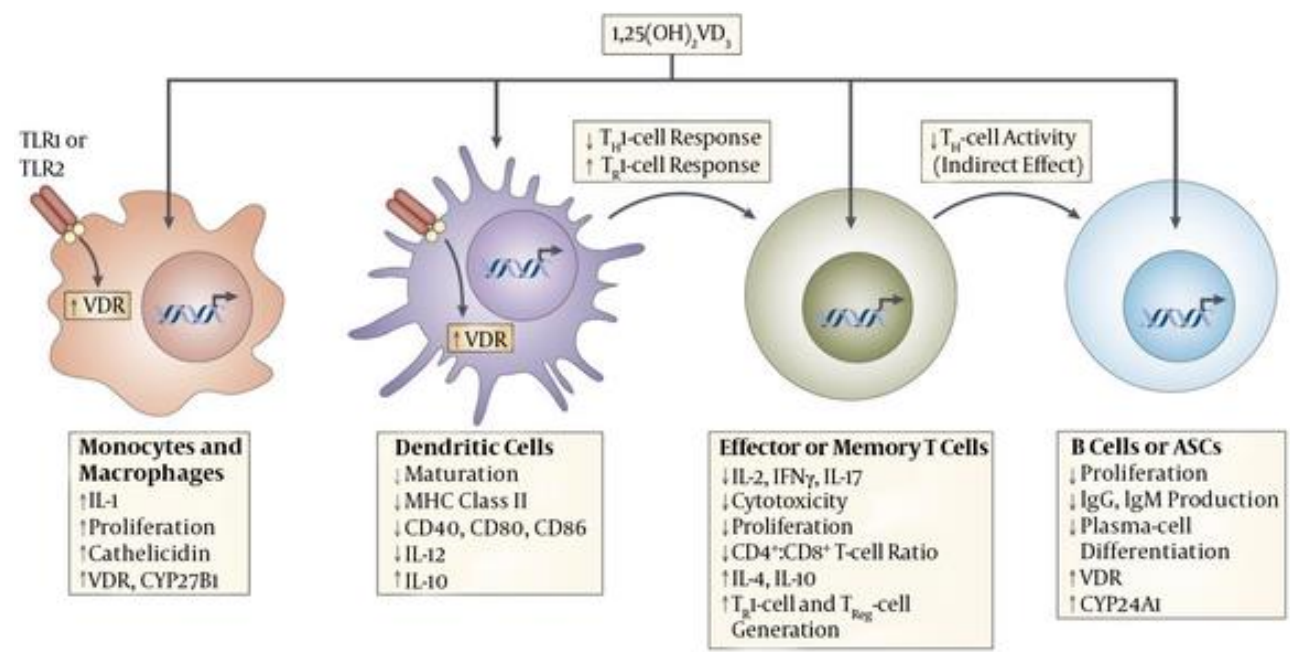

Figure 1. The mechanisms of vitamin D immunomodulation [42].

ISSN 2706-6282(print)

ISSN 2706-6290(online)
Вісник медичних і біологічних досліджень

Bulletin of Medical and Biological Research
$4(10), 2021$ 
decreased rates of Vit $D$ deficiency and low rate of COVID-19 mortality rate in their countries) and nations which are located in low latitudes (with considerable values of Vit D deficiency and high rate of COVID-19 mortality rate such as Indonesia and the Philippines) has been done and its detailed data has been reported [9]. In a recent published article effect of Vit D and A on probable prevention of COVID-19 infection has been reviewed by authors [10]. Although there are some data about association between COVID-19 infection and Vit $\mathrm{D}$, but there is no available study which can approve that how much this association is considerable, so clinical trials and in vivo and/or in vitro studies in this area are highly recommended.

As far as you can see at the Figure 2, vitamin C takes part in the development and functionality of various immune cells and the production of antibodies. The contribution of vitamin $C$ in immune response has been suggested due to the enhancement of different cellular functions of innate and adaptive immunity. Vitamin $\mathrm{C}$ enhances the function of epithelial barrier against pathogens and stimulates skin scavenging activity to protect against the environmental oxidative stress. In addition, it could accumulate in neutrophils to promote chemotaxis phagocytosis and with subsequent microbial killing. It is also required for apoptosis and neutrophil clearance from the infection sites, which resulted in a reduction of necrosis and possible tissue damage. In B and T lymphocytes, vitamin $\mathrm{C}$ might promote the cellular differentiation and proliferation due to its gene-regulating activities. Therefore, the deficiency of vitamin $\mathrm{C}$ may result in immunity impairment and increased susceptibility to infections. Therefore, infections may have a significant effect on level of vitamin $C$ because of inflammation enhancement. Interestingly, vitamin C supplementation seems to be able to prevent and treat the respiratory and systemic infections.

Vitamin E, as a well-known antioxidant, also has functions in regulating the immune response. Meanwhile, numerous studies showed that supplementation with vitamin $E$ could have harmful effects on the immune system, especially in cancer and cardiovascular diseases. There was no conclusive evidence of the role of vitamin $E$ in the treatment of COVID-19, but it is believed that vitamin $E$ protects the integrity of cell membranes from damage caused by free radicals and has the potential to influence both innate and adaptive immunity.

Trace minerals are an essential component of the diet. Their regulatory effects on immune function have been well defined, and inadequate levels of trace elements have been reported to alter immune competence in humans $[11,12]$. Prolonged dietary deficiencies of trace minerals may result in impaired immune function by influencing one or more components of the immune system [13]. Although the specific functions of minerals in protecting or boosting human immunity are not well understood, several trace elements such as zinc, magnesium, iron, copper, selenium, and manganese have gained wide recognition for their roles in maintaining optimal health.

In this COVD19 situation, zinc is considered as a supportive treatment therapy as it has direct antiviral effects. It is found that zinc supplementation may have positive effects in the treatment of COVID 19 patient. The role of zinc in immunity is explained in many studies. Zinc deficiency can cause loss of $T$ helper

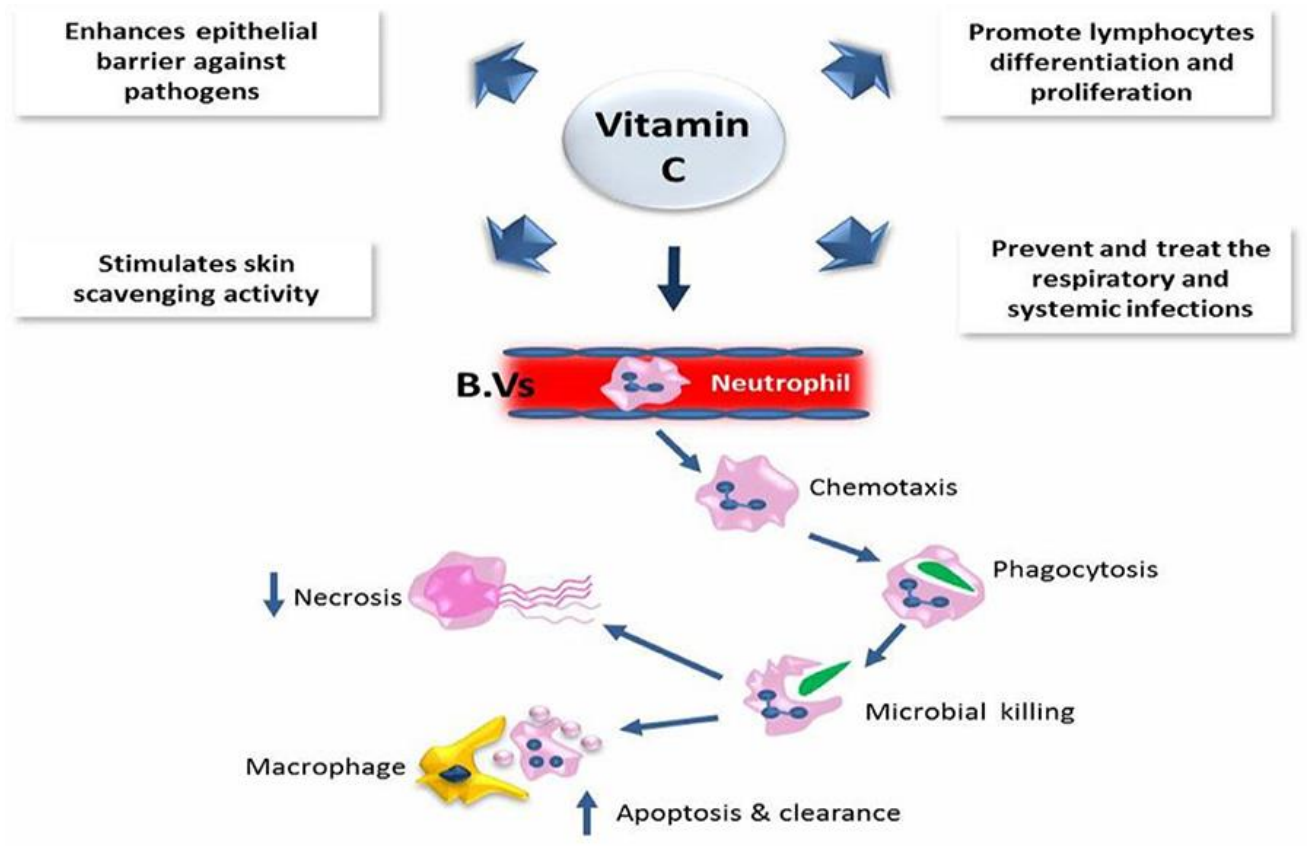

Figure 2. The role of vitamin $C$ in the immune defense [43] 
cells and also responsible for atrophy of thymus and spleen. Zinc increases the IgM plaque response and IgG response. Cell mediated immunity is also increased with zinc supplementation. T-lymphocyte proliferation is also maintained by proper dietary intake of zinc. Some meta-analysis found that zinc decreased the prevalence and incidences of pneumonia as well as duration of common cold. The common sources of zinc are meat, cheese, cereals and grains, shellfish etc (Fig. 3).

Zinc regulates the signaling pathways in the cells of both specific and non-specific immunity [14]. Disorders in the homeostasis of zinc alter the immune response in several ways, resulting in abnormal lymphopoiesis, disturbed intercellular cytokine signaling, and weakening the innate immune response through phagocytosis and oxidative burst [15]. Zinc deficiency is a very common disorder, and almost 1/5 of the global population is at risk [16]. The lack of zinc impedes the immune response, reduces pathogenic resistance, and extends the duration and incidence of pneumonia [17]. In the elderly population, dietary supplementation of zinc increases the IL-2 and IL-2R- $\alpha$ mRNA expressions in peripheral blood mononuclear cells (PBMCs) [18]. Recent studies showed that zinc affects the polarization of CD4+ T cells on behalf of Th1. In contrast, the up-regulation of IL-12 signaling and transcription factor T-bet activity leads to an increase of IFN-y [19, 17] investigated the effects of dietary supplementation with zinc (30 mg/day for 3 months). They reported an increase in zinc concentrations in serum, which was associated with peripheral $\mathrm{T}$ cell numbers [20]. High intracellular concentrations of zinc with zinc ionophores such as pyrithione can harm the replications of several RNA viruses [21]. Concerning the global crisis of the COVID-19 pandemic, the use of zinc as possible supportive treatment in COVID-19 patients could be attributed to its immune enhancement effect and direct antiviral activity [22]. In particular, $\mathrm{Zn}^{2+}$ cations combined with $\mathrm{Zn}$ ionophore pyrithione have a role in inhibition of SARS-coronavirus RNA polymerase

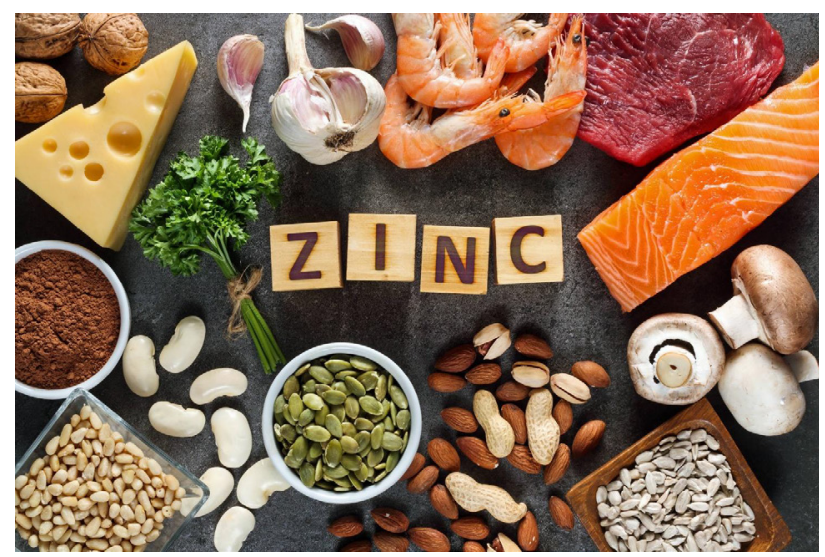

Figure 3. Dietary sources of zinc [44].
(RNA-dependent RNA polymerase, RdRp) activity via reduction of viral replication [21]. Interestingly, recent trials concluded the antiviral activity of chloroquine against COVID-19 [23], where they suggested that chloroquine has increased flux of zinc into the cell [24]. In continuous context, it was suggested that increased concentration of zinc inside cells by chloroquine could enhance the antiviral effect of zinc against SARSCoV-2 [25]. Similarly, supplementation of zinc without chloroquine may have similar desired effects without the deleterious side effects of chloroquine [26]. Another theory for COVID-19 treatment includes targeting Zn ions in the viral protein structure; for instance, in MERSCoV and SARS-CoV, the antiviral drug disulfiram induced release of zinc from papain-like protease leading to destabilization of viral protein [27]. Based on such findings, dietary supplementation with zinc could have positive effects not only on the relief of symptoms related to COVID-19 but also on the virus itself [22].

Another risk factor that can cause acute infections in the respiratory system is iron deficiency [22]. Both hosts and pathogens use iron. Iron deficiency can weaken the immune system, while excessive amounts of iron can cause oxidative stress that promotes mutations of viruses [28]. Hemoglobinopathy, hypoxia, and cell iron overload might have a potential additional role. Scientific reports have stated two possible pathophysiological mechanisms: (i) severe acute respiratory syndrome-coronavirus-2 interaction with hemoglobin molecule, through CD26, CD147, and other receptors located on erythrocyte and/or blood cell precursors; (ii) hepcidin-mimetic action of a viral spike protein, inducing ferroportin blockage [29].

Selenium has essential roles in the immune response, mostly by incorporating it into selenoproteins [30]. Selenium may have a significant place in COVID-19 management, particularly in vulnerable elderly, and might represent a game changer in the global response to COVID-19. Nuclear factor kappaB (NF-kB) signaling pathway plays a role in COVID-19 progression and selenium is a NF-kB inhibitor.

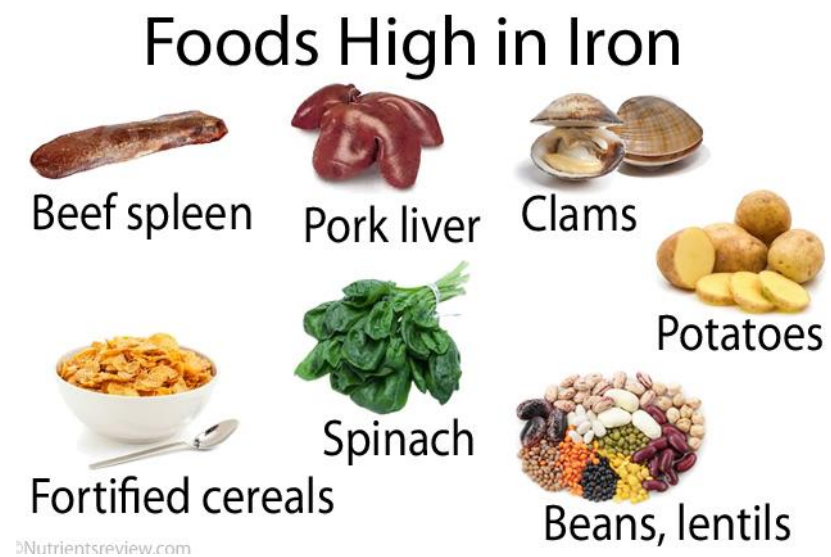

Figure 4. Dietary sources of iron [45].
ISSN 2706-6282(print)

ISSN 2706-6290(online)
Вісник медичних і біологічних досліджень Bulletin of Medical and Biological Research
$4(10), 2021$ 
Selenium might reduce the effect of SARS-CoV-2 on vascular endothelial cells and aggregation of platelets [31]. Supplementing COVID-19-affected patients with selenium might be an efficient way to treat and prevent the novel coronavirus [32]. The synergistic use of selenium with saponins from ginseng stem leaf could activate the immune responses to a live bivalent vaccine of infectious bronchitis coronavirus in chickens [33]. The dietary supplementations of selenium (Fig.5) could represent an effective method for treating the novel virus of COVID-19 [22]. Regarding the aforementioned effects of zinc and selenium, we suggest that dietary supplementation with these two microelements may improve the immune response to viral infections. The suggested dosage for zinc is 20 $\mathrm{mg}$ per day while that for selenium is $50 \mu \mathrm{g}$ per day.

Phosphorus $(P)$ is an essential constituent of many important primary cell metabolites such as nucleic acids, phospholipids, lipopolysaccharides, and different cytoplasmic solutes [34, 35, 36]. P has been suggested in various studies with different species to perform an important role in the immune system and the modulation of $P$ level in the diet could modulate the function and migration of immune cells [34, 35]. Similarly, $\mathrm{Ca}$ is a normal body constituent and is critical for the immune responses [36]. Calcium phosphate (CaP) in the form of microparticle or nanoparticle has been used as potential adjuvants or vaccine carrier (delivery system) for DNA and peptide vaccines for humans and mammals. CaP nanoparticles have a number of advantages over other inorganic particles. Their biodegradability and biocompatibility are excellent [37]; they are native to the body, well-tolerated and absorbed in the body, non-toxic, cost-effective, and easily manufactured and have a high affinity to protein, DNA, antigens, and chemotherapy drugs [38]. Calcium phosphate has been used for many

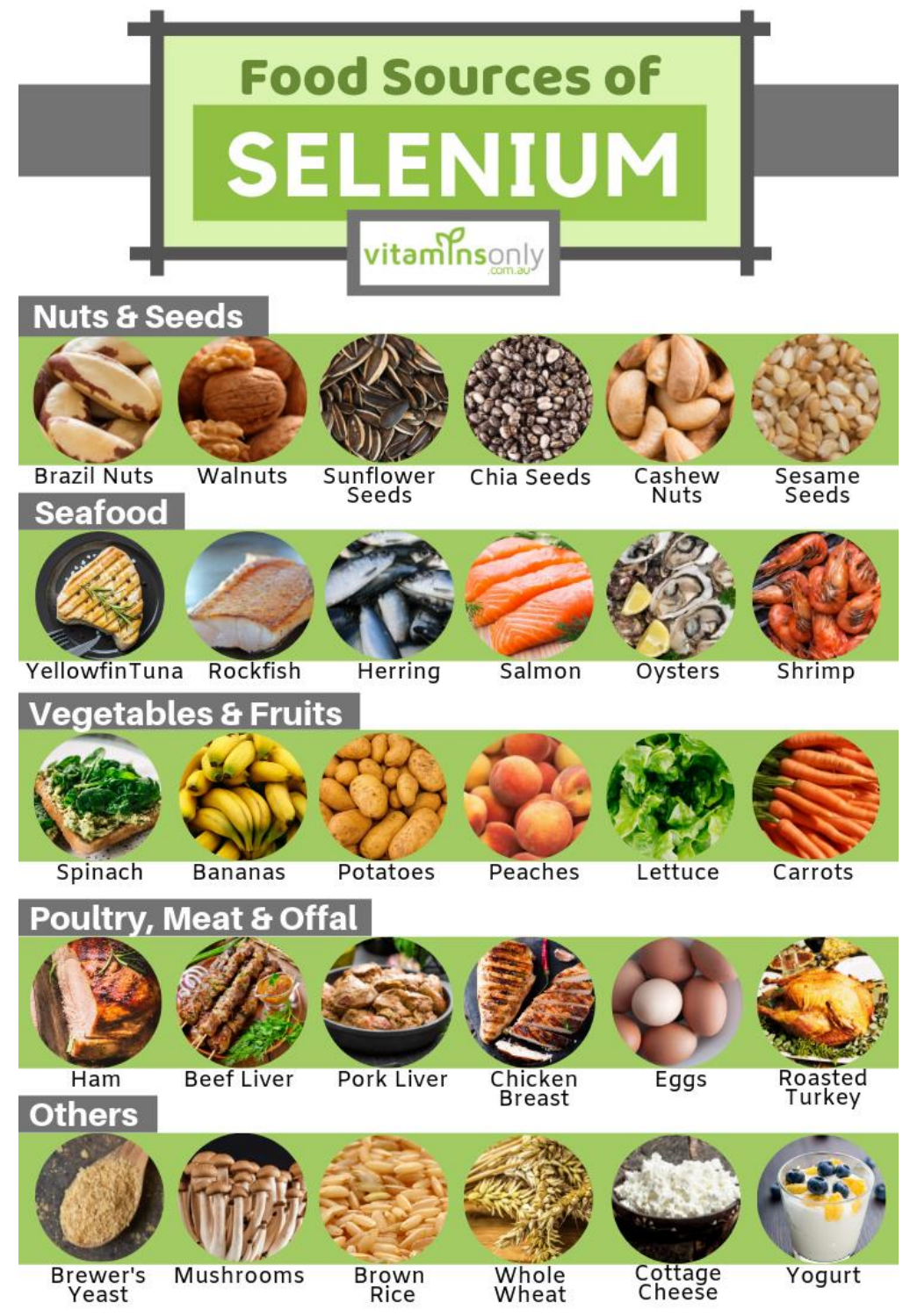

Figure 5. Dietary sources of selenium [46]. 
years as the adjuvant for diphtheria-tetanus-pertussis (DTP) vaccine and other vaccines. CaP nanoparticles have been used to couple several viruses like EpsteinBarr virus and Herpes simplex virus-2, a potent mucosal adjuvant, and induce both mucosal and cell-mediated immunity to nucleotide vaccines in humans and were used in glycoprotein vaccine [39, 40, 41]. Additionally, CaP nanoparticles have also been reported to possess better stimulation of both innate and adaptive immunity in mice

Suggestions and Recommendations. With the current emphasis on exploring therapeutic options to treat COVID-19, more than 100 clinical trials are under way to develop a vaccine, design effective drugs, and test novel and repurposed compounds against SARS-CoV-2. However, data from longitudinal and observational studies on the extent of micronutrient deficiencies in COVID-19 patients, along with infection severity scores, are needed. Factors predicted to be associated with high risk of severe COVID-19 include age above 50 years, male gender, smoking, chronic kidney disease, diabetes, cardiovascular disease, chronic obstructive pulmonary disease, and cerebrovascular disease. Individuals with these risk factors should be screened for micronutrient deficiencies. Supplementation to achieve adequate serological levels of the deficient nutrients may be provided in accordance with in-practice guidelines. The impact of supplementation should be evaluated relative to reductions in the severity of infection and improvements in the recovery index.

The role of optimal nutrition for managing the current COVID-19 pandemic cannot be underestimated. Nutrition has a demonstrable role in the prevention and treatment of moderate to severe respiratory and

\section{REFERENCES}

1. Nasri H, Baradaran A, Shirzad H, Rafieian-Kopaei M. New concepts in nutraceuticals as alternative for pharmaceuticals. Int J Prev Med. 2014;5: 1487-99.

2. Chen YH, Chang GK, Kuo SM, Huang SY, Hu IC, Lo YL, et al. Well-tolerated Spirulina extract inhibits influenza virus replication and reduces virus-induced mortality. Sci Rep. 2016;6: 24253. DOI: 10.1038/srep24253

3. Wintergerst ES, Maggini S, Hornig DH. Contribution of selected vitamins and trace elements to immune function. Ann Nutr Metab. 2007;51: 301-23. DOI: 10.1159/000107673

4. Grant WB, Lahore H, McDonnell SL, Baggerly $\mathrm{CA}$, French $\mathrm{CB}$, Aliano JL, et al. Evidence that vitamin $D$ supplementation could reduce risk of influenza and COVID-19 infections and deaths. Nutrients. 2020;12: 988. DOI: $10.3390 /$ nu12040988

5. Miller ER, Pastor-Barriuso R, Dalal D, Riemersma RA, Appel LJ, Guallar E. Meta-analysis, high-dosage vitamin E supplementation may increase all-cause mortality. Ann Intern Med. 2005;142: 37-46. DOI: 10.7326/0003-4819142-1-200501040-00110 nonrespiratory infections. Adequate nutrition is even more essential for marginalized communities and in low- and middle-income countries, where deficiencies in key vitamins and minerals expose individuals to greater morbidity and mortality. Low- and middleincome countries should strategize to ensure the population at large has access to optimal nutrition to boost the immune system and should provide specific supplementation for treatment of COVID-19 patients, especially those with severe disease. Older adults represent a high-risk population and may be prioritized to receive care in nursing facilities and to receive specialized nutritional support to improve physical and mental outcomes of the COVID-19 pandemic.

\section{CONCLUSIONS}

1. Despite the fact that the exact intracellular mechanisms of immunostimulatory action of nutrients have not been fully studied, there is much evidence of their beneficial effects on the body's immune system, as well as their proven antioxidant and anti-inflammatory activity.

2. Nutrition has a demonstrable role in the prevention and treatment of moderate to severe respiratory and nonrespiratory infections. Adequate nutrition is even more essential for marginalized communities and in low- and middle-income countries, where deficiencies in key vitamins and minerals expose individuals to greater morbidity and mortality.

3. Low- and middle-income countries should strategize to ensure the population at large has access to optimal nutrition to boost the immune system and should provide specific supplementation for treatment of COVID-19 patients, especially those with severe disease.

6. Schwalfenberg GK. A review of the critical role of vitamin $D$ in the functioning of the immune system and the clinical implications of vitamin D deficiency. Mol Nutr Food Res. 2011;55(1): 96-108. DOI: 10.1002/mnfr.201000174. [PubMed: 20824663].).

7. Cantorna MT. Mechanisms underlying the effect of vitamin $D$ on the immune system. Proc Nutr Soc. 2010;69(3): 286-9. DOI: 10.1017/S0029665110001722. [PubMed: 20515520]. [PubMed Central: PMC3138329]

8. Grant WB, Lahore $\mathrm{H}$, McDonnell SL, Baggerly $\mathrm{CA}$, French $\mathrm{CB}$, Aliano JL, et al. Evidence that vitamin $D$ supplementation could reduce risk of influenza and COVID-19 infections and deaths. Nutrients. 2020;12(4). DOI: 10.3390/nu12040988. [PubMed: 32252338]. [PubMed Central: PMC7231123]

9. Braiman M. Latitude dependence of the COVID-19 mortality rate-a possible relationship to vitamin D deficiency? SSRN Electronic Journal. 2020. DOI: 10.2139/ ssrn.3561958
$4(10), 2021$ 
10. Jayawardena R, Sooriyaarachchi $P$, Chourdakis $M$, Jeewandara $C$, Ranasinghe $P$. Enhancing immunity in viral infections, with special emphasis on COVID-19: A review. Diabetes Metab Syndr. 2020;14(4): 367-82. DOI: 10.1016/j. dsx.2020.04.015. [PubMed: 32334392]. [PubMed Central: PMC7161532].).

11. Shankar AH, Prasad AS. Zinc and immune function: the biological basis of altered resistance to infection. Am J Clin Nutr. 1998;68(2 suppl): 447S-463S. DOI:10.1093/ ajcn/68.2.447S [PubMed] [CrossRef] [Google Scholar]

12. Sherman AR. Zinc, copper, and iron nutriture and immunity. J Nutr. 1992;122(3 suppl): 604-9. [PubMed] [Google Scholar

13. Keen CL, Uriu-Adams JY, Ensunsa JL, et al.Trace elements/minerals and immunity In: Gershwin ME, Nestel $P$, Keen CL, eds. Handbook of Nutrition and Immunity. Humana Press; 2004: 117-40. [Google Scholar]

14. Wessels I, Maywald M, Rink L. Zinc as a gatekeeper of immune function. Nutrients. 2017;9: 1286. DOI: 10.3390/ nu9121286

15. Maares $M$, Haase $H$. Zinc and immunity: an essential interrelation. Arch Biochem Biophys. 2016;611: 58-65. DOI: 10.1016/j.abb.2016.03.022

16. Wessells $\mathrm{KR}$, Brown $\mathrm{KH}$. Estimating the global prevalence of zinc deficiency, results based on zinc availability in national food supplies and the prevalence of stunting. PLoS ONE. (2012) 7:e50568. DOI: 10.1371/ journal.pone.0050568

17. Barnett JB, Hamer DH, Meydan SN. Low zinc status, a new risk factor for pneumonia in the elderly? Nut Rev. 2010;68: 30-7. DOI: 10.1111/j.17534887.2009.00253.x

18. Prasad AS, Bao B, Beck FW, Sarkar FH. Correction of interleukin-2 gene expression by in vitro zinc addition to mononuclear cells from zinc-deficient human subjects, a specific test for zinc deficiency in humans. Transl Res. 2006;148: 325-33. DOI: 10.1016/j.trsl.2006.07.008

19. Bao B, Prasad AS, Beck FW, Bao GW, Singh T, Ali S, et al. Intracellular free zinc up-regulates IFN-gamma and T-bet essential for Th1 differentiation in Con-A stimulated HUT-78 cells. Biochem Biophys Res Commun. 2011;407: 703-7. DOI: 10.1016/j.bbrc.2011.03.084

20. BarnettJB, Dao MC, HamerDH, Kandel R, Brandeis G, Wu $D$, et al. Effect of zinc supplementation on serum zinc concentration and $T$ cell proliferation in nursing home elderly, a randomized, double-blind, placebo-controlled trial. Am J Clin Nut. 2016;103: 942-51. DOI: 10.3945/ajcn.115.115188

21. Te Velthuis AJ, van den Worm SH, Sims AC, Baric RS, Snijder EJ, van Hemert MJ. Zn2+ inhibits coronavirus and arterivirus RNA polymerase activity in vitro and zinc ionophores block the replication of these viruses in cell culture. PLoS Pathogens. 2010;6: e1001176. DOI: 10.1371/ journal.ppat.1001176

22. Zhang L, Liu Y. Potential interventions for novel coronavirus in China, a systematic review. J Med Virol. 2020;92: 479-90. DOI: 10.1002/jmv.25707

23. Wang M, Cao R, Zhang L, Yang X, Liu J, Xu M, et al. Remdesivir and chloroquine effectively inhibit the recently emerged novel coronavirus (2019-nCoV) in vitro. Cell Res. 2020;30: 269-71. DOI: 10.1038/s41422-020-0282-0

24. Xue J, MoyerA, Peng B, Wu J, Hannafon BN, Ding WQ. Chloroquine is a zinc ionophore. PLoS ONE. 2014;9: e1091802014. DOI: 10.1371/journal.pone.0109180
25. Skalny AV, Rink L, Ajsuvakova OP, Aschner M, Gritsenko VA, Alekseenko S, et al. Zinc and respiratory tract infections: perspectives for COVID 19 (Review). Int J Mol Med. 2020;46: 17-26. DOI: 10.3892/ijmm.2020.4575

26. Guastalegname M, Vallone A. Could chloroquine/ hydroxy-chloroquine be harmful in Coronavirus disease 2019 (COVID-19) treatment? Clin Infect Dis. 2020;71: 8889 DOI: 10.1093/cid/ciaa321

27. Lin MH, Moses DC, Hsieh $\mathrm{CH}$, Cheng SC, Chen YH, Sun CY, et al. Disulfiram can inhibit MERS and SARS coro-navirus papain-like proteases via different modes. Antiviral Res. 2018;150: 155-63. DOI: 10.1016/j. antiviral.2017.12.015

28. Wessling-Resnick M. Crossing the iron gate, why and how transferrin receptors mediate viral entry. Annu Rev Nutr. 2018;38: 431-58. DOI: 10.1146/annurevnutr-082117-051749

29. Cavezzi A, Troiani E, Corrao S. COVID-19: hemoglobin, iron, and hypoxia beyond inflammation. A narrative review. Clin Pract. 2020;10: 1271. DOI: 10.4081/ cp. 2020.1271

30. Hoffmann PR, Berry MJ. The influence of selenium on immune responses. Mol Nutr Food Res. 2008;52: 127380. DOI: $10.1002 / \mathrm{mnfr} .200700330$

31. Hiffler L, Rakotoambinina B. Selenium and RNA viruses interactions: potential implications for SARS-Cov-2 infection (Covid-19). Front Nutr. 2020;7. DOI: 10.31219/osf. io/vaqz6

32. Guillin OM, Vindry C, Ohlmann T, Chavatte L. Selenium, selenoproteins and viral infection. Nutrients. 2019;1: 2101. DOI: 10.3390/nu11092101

33. Ma X, Bi S, Wang Y, Chi X, Hu S. Combined adjuvant effect of ginseng stem-leaf saponins and selenium on immune responses to a live bivalent vaccine of Newcastle disease virus and infectious bronchitis virus in chickens. Poult Sci. 2019;98: 3548-56. DOI: 10.3382/ ps/pez207

34. Liu N, Ru YJ, Cowieson AJ, Li FD, Cheng XCh. Effects of phytate and phytase on the performance and immune function of broilers fed nutritionally marginal diets. Poult Sci. 2008;87: 1105-11. DOI: 10.3382/ps.2007-00517

35. Chen K, Jiang WD, Wu P, Liu Y, Kuang SY, Tang L, et al. Effect of dietary phosphorus deficiency on the growth, immune function and structural integrity of head kidney, spleen and skin in young grass carp (Ctenopharyngodon idella). Fish Shellfish Immunol. 2017;63: 103-26. DOI: 10.1016/j.fsi.2017.02.007

36. Chen K, Zhou XQ, Jianga WD, Wu P, Liu Y, Jiang J, et al. Dietary phosphorus deficiency caused alteration of gill immune and physicalbarrier function in the grass carp (Ctenopharyngodon idella) after infectionwith Flavobacterium columnare Aquaculture. 2019;506: 1-13. DOI: 10.1016/j.aquaculture.2019.03.018

37. Sokolova VV, Radtke I, Heumann R, Epple M. effective transfection of cells with multi-shell calcium phosphate-DNA nanoparticles. Biomaterials. 2006;27: 3147-53. DOI: 10.1016/j.biomaterials.2005.12.030

38. Behera T. Priyabrat Swain-antigen adsorbed calcium phosphate nanoparticles stimulate both innateand adaptive immune response in fish, Labeo rohita $\mathrm{H}$. Cell Immunol. 2011;271: 350-9. DOI: 10.1016/j.cellimm.2011.07.015

39. Goto N, Kato H, Maeyama J, Eto K, Yoshihara S. Studies on the toxicities of aluminium hydroxide and calcium 
phosphate as immunological adjuvants for vaccines. Vaccine. 1993;11: 914-8. DOI: 10.1016/0264-410X(93)90377-A

40. He Q, Mitchell AR, Johnson SL, Bartak CW, Morcol T, Bell SJ. Calcium phosphate nanoparticle adjuvant. Clin Diagn Lab Immunol. 2000;7: 899-903. DOI: 10.1128/ CDLI.7.6.899-903.2000

41. He Q, Mitchell AR, Morcol T, Bell Steve JD. Calcium phosphate nanoparticles induce mucosal immunity and protection against herpes simplex virus type 2. Clin Diagn Lab Immunol. 2002;9: 1021-4. DOI: 10.1128/CDLI.9.5.10211024.2002

42. Mora JR, Iwata M, von Andrian UH. Vitamin effects on the immune system: vitamins $A$ and $D$ take centre stage. Nat Rev Immunol. 2008;8(9): 685-98. DOI:10.1038/nri2378
43.AlagawanyM,AttiaYA, FaragMR, ElnesrSS, NagadiSA, Shafi ME, Khafaga AF, Ohran H, Alaqil AA, Abd El-Hack ME. The strategy of boosting the immune system under the COVID-19 pandemic. Front Vet Sci. 2021;8;7: 570748. DOI: 10.3389/fvets.2020.570748. PMID: 33490124; PMCID: PMC7820179

44. https://www.vitabiotics.com/blogs/health-areas/ best-sources-of-zinc

45. https://juliawebmd.wordpress.com/2016/04/08/howis-my-blood-composed-inside-my-body/)

46. https://u.osu.edu/whitacre.44/metals-selenium/)

Received 02.09.21 